A R C H I V E

O F

M E C H A N I C A L

E N G I N E E R I N G

\begin{tabular}{lll}
\hline VOL. LXI & 2014 & Number 1
\end{tabular}

10.2478/meceng-2014-0011

Key words: stress gradient, platform of plasticity plastic zone, optical interference

STEFAN BUĆKO *, HENRYK JODEOWSKI ${ }^{* *}$, MARCIN TRZEBICKI ${ }^{* * *}$

\title{
AN EXPERIMENTAL-NUMERICAL ANALYSIS OF PLASTIC ZONES INITIATION AROUND HOLES IN SHIELDS MADE OF STEEL C45 UNDER TENSION
}

\begin{abstract}
The paper presents the results of research on the plastic zones formation in thin (3.51 [mm]) shields made of steel C45 with holes of 4, 10 and 20 diameters. The authorship method of identifying plastic macro-strains utilizing optical interference phenomenon was used in the experiments. The basic idea of the method is summarized below as being: "The occurrence of plastic deformations in the active process of loading is testified by a loss of the interference fringes that were previously present or by a clear and rapid change in their character". In the experiments, the values of the stress initiating the first plastic deformation were determined. In order to explain the processes of plastic deformation appearance a detailed stress state analysis in the holes surrounding area was realized with the use of Finite Element Method. Comparison of experimental results with the results of FEM calculations indicates that there are significant quantitative as well as qualitative differences. Namely stresses initiating plastic deformations clearly exceed the value of $R_{e H}$, and plastic deformation are of local plastic slides character. Similar results were previously obtained in studies on the shields made of steel $15 \mathrm{CrMo}$ with holes.
\end{abstract}

\section{Introduction}

The research conducted at the Institute of Applied Mechanics, Cracow University of Technology into the problem of the initial phase of plastic deformation around the hole in the thin steel 15CrMo shield e.g. [3], [5] showed the presence of a new, unusual shape of the plastic zone and also the presence of the stresses initiating plastic deformation that significantly

* Instytut Mechaniki Stosowanej, Politechnika Krakowska, Wydziat Mechaniczny, Al. Jana Pawła II 37a, 31-864 Kraków, Poland; E-mail: s_bucko@mech.pk.edu.pl

** Instytut Mechaniki Stosowanej, Politechnika Krakowska, Wydziat Mechaniczny, Al. Jana Pawta II 37a, 31-864 Kraków, Poland; E-mail: abies@mech.pk.edu.pl

*** Instytut Konstrukcji Maszyn, Politechnika Krakowska, Wydziat Mechaniczny, Al. Jana Pawła II 37a,31-864 Kraków, Poland;E-mail: mtrzeb@mech.pk.edu.pl 
exceeded a distinct yield point value. The values of stresses initializing the first plastic slip round the hole in experiments performed previously [3], [5], [8] exceeded the yield value by over $40 \%$ for holes whose diameters were several times $(4.5 \div 6.5)$ bigger than the shield thickness. One of these results has been positively verified on the shield specimen made of the same steel sheet $15 \mathrm{CrMo}$ with the use of unloading method [3]. These results differ significantly from the results of other authors e.g. [6], [12], who did not carry out a verification of the actual nature of the strains at the time when the maximum stress reached the yield point. The authors of the above-mentioned works assumed that fulfilling the yield criteria, i.e. when the product of experimentally determined deformations and the Young's Modulus reaches the yield point in at least one point, means that plastic deformations have begun.

In [5], besides the presentation of the experiment, a numerical analysis of the stress states around the holes of two different quotients of diameters to the shield thickness was also shown. The shape of the plastic zone in the initial phase obtained experimentally in [3], [5], [8] is significantly different from that presented in the literature based on the fulfilment of the condition of plasticity even at one point as a criterion for the formation of plastic deformation.

This paper presents the results of an examination of C45 steel shields with holes together with the stress analysis performed with the use of the finite element method. The detailed analysis of the stress state around the hole without restrictions resulting from the assumption of the plane stress state allows for a more complete view on the process of plastic zone formation.

The aim of this study is to verify the effectiveness of the optical interference method in identifying plastic deformation around the holes in the shields of steel C45. The authors have also made an attempt to determine the stresses initializing the plastic zone together with showing the shape of this area in the initial phase. To evaluate the results of the experiments described in the work, it is interesting to compare the shape of the plastic zones of both $\mathrm{C} 45$ and $15 \mathrm{CrMo}$ steels.

\section{Test method (research methodology)}

\subsection{Characteristics of method of plastic macro-strain identification with the use of optical interference}

Macro-strain identification method in steels with plastic material instability uses optical interference phenomenon occurring when viewed highly polished metal surface through half-permeable mirror, in the monochromatic 
light, by placed the specimen very close to the mirror (but without direct contact). Interference occurs between part-rays passed through the semipermeable mirror and reflected from the polished surface of the sample and the second part-rays reflected from the half-permeable mirror. Interference fringes, visible on the sample surface, can be interpreted as the lines of constant distance between the half-permeable mirror and the polished sample surfaces.

The basic idea of the plastic strain identification method with the use of optical interference can be summarized as follows:

"The occurrence of plastic deformations in steel with material instability in the active process of loading is testified by a loss of the interference fringes that were previously present or by a clear and rapid change in their character".

The discussed method uses the phenomenon that plastic deformation in steels of material instability rely on plastic slides in grains and grain movements causing warping of the sample surface and scatter reflected light resulting in the loss of the optical interference fringes.

Two types of changes in interference fringes layouts at the moment of plastic strains occurrence were distinguish in the authors' works [3], [8], [9]: a loss of interference fringes or significant and rapid change of the fringes character.

In the most of the experiments, the loss of interference fringes was observed i.e. for S235, S355, 15CrMo, 18G2A, Armco iron, what does not exhaust the entire list. Significant changes in the interference fringes at the onset of plastic deformations in C45 steel as well as in 34CrNiMo6 steel in the state after normalization annealing were observed.

In the research on plastic deformation initiation with the use of optical interference method, the video movie recording of interference fringes change was conducted. The film registration was synchronized in time with accurate measurements of force and elongation (extensometer) or with the strain gauge measurements at selected locations of the sample.

That way the sample elongation or strain measured by strain gauge, the value of the loading force and the corresponding video frames of film were assigned to the every moment of time. This allowed for preparing (e.g. for $15 \mathrm{CrMo}$ steel characterized by high plasticity) the graph shown in the image (Fig. 1).

Plastic deformations occur in one or more random sample places. In the presented example, plastic deformation beginning occurred outside the observed sample region. However, the registration system of experiment progress allowed for assigning of each phenomenon (plastic slip) in the ob- 

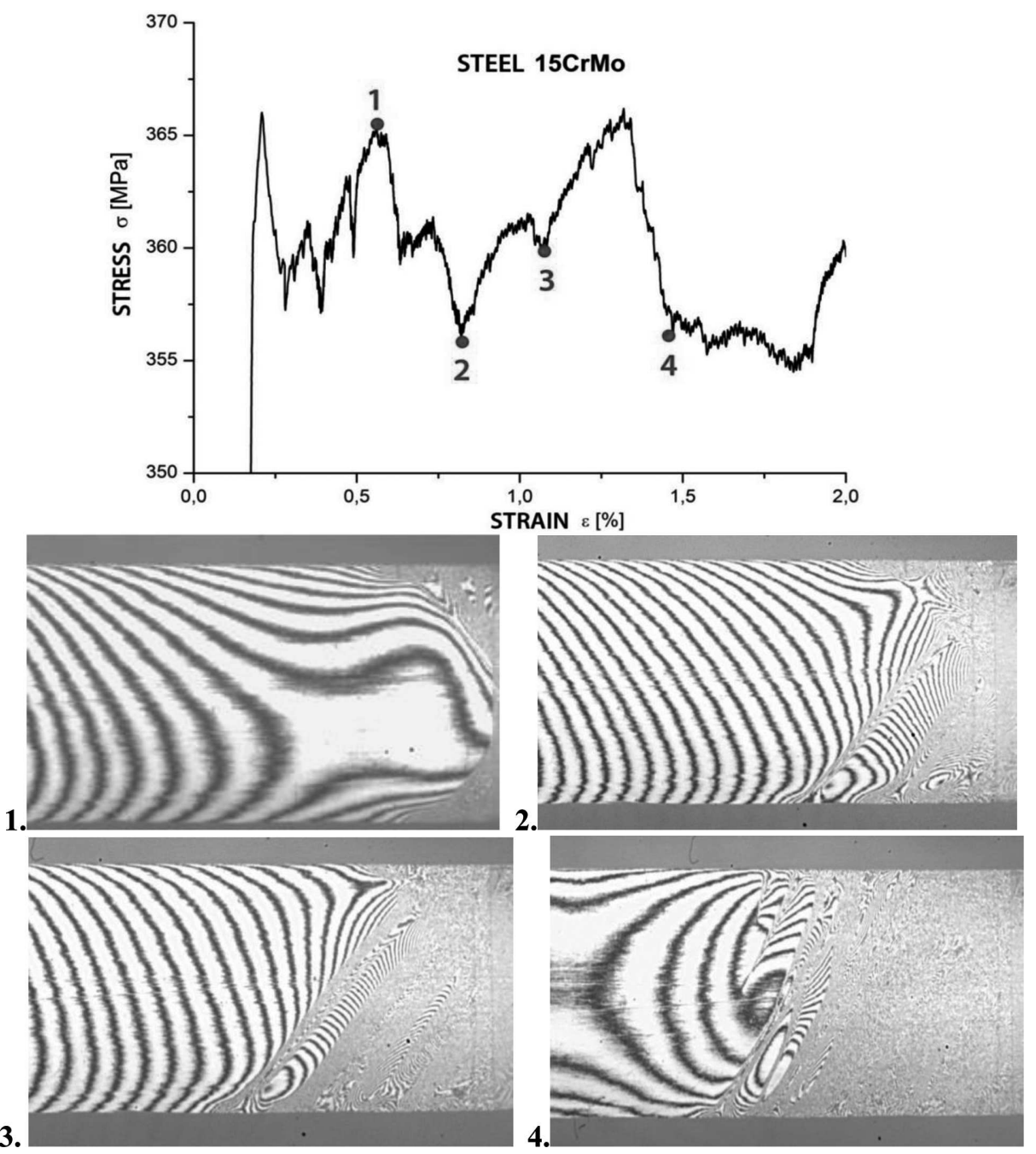

Fig. 1. Platform of plasticity for $15 \mathrm{CrMo}$ steel (15HM) with marked points $(\sigma-\varepsilon)$ and responding to them pictures of interference fringes

served area of the sample to the corresponding point of the plastic platform on the exact tensile test graph.

Figure 1 shows four numbered images of interference fringes, and the placement of points, marked on the strain-stress graph, that represent the corresponding physical states. The analysis of states shown in Figure 1 shows the propagation of the plastic zone along of the sample length. This indicates that the nature of the observed plastic deformations is initially local. The bands of rapidly disappearing fringes, looking like the grain blocks being detached, appear usually near the local extremes on the tensile curve. Another such bands form at a distance from the previous ones, while the fringes blink 
and vanish slowly in the areas between the bands. This reflects the increasing plastic deformation in these zones.

The three zones, differing in interference fringes system, are usually visible side by side during the plastic flow. These are: the elastic zone, the plastic zone and the zone of plastic deformation development.

The onset of plastic deformations causes vanishing of interference fringes for the most of steels with material instability, which can be seen in the accompanying set of charts and photographs made for the steel $15 \mathrm{CrMo}-$ then $15 \mathrm{HM}$ - Figure 1 . The choice of $15 \mathrm{CrMo}$ steel $(15 \mathrm{HM})$ for the method presentation was dictated by the long plastic platform $(\approx 2.8 \%)$ and a classic type of its behaviour.

The material of C45 steel shields, investigated in the work, responds to the formation of plastic deformation with significant and fairly rapid change in the interference fringes layout. This issue will be discussed in detail in Section 3 of this paper.

To analyse the stress state around the holes in the test shields the finite element method Algor system was used. The calculations, whose results are given in the work, were performed assuming a linear elastic material for the load corresponding to the assumption that elastic bearing capacity was reached.

\subsection{Technical details of the experiment}

The steel C45 shields had dimensions $500 \times 88.4 \times 3.51[\mathrm{~mm}]$, and before the performance of tests they were annealed at $700^{\circ} \mathrm{C}$ and cooled within the furnace. The tests were performed for disks with holes of three different diameters, namely $4[\mathrm{~mm}](\phi 4), 10[\mathrm{~mm}](\phi 10)$ and $20[\mathrm{~mm}](\phi 20)$. Two strain gauges of the base of 3.0 [mm] were glued symmetrically (Fig. 2) onto the lateral surfaces of the $\phi 10$ and $\phi 20$ holes, and the task of these gauges was to measure the strains in order to signal nonlinear changes in deformations or discontinuities of the deformations, considered as the signal of the occurrence of plastic slips. The relatively large length of the measurement base of the strain gauges makes it difficult to use them for direct measurement of extreme strains on the lateral surface of the hole, because of large stress gradients in their maximum zone. It was not possible to place the strain gauges on the side surface of the $\phi 4$ hole. During the tension of shields with holes of $\phi 10$ and $\phi 20$, one synchronously registered the tensile force, the strain gauges indications and the images of interference fringes captured with the use of a camera. For a disk with a hole of $\phi 4$, the tensile force was registered and the changes in interference fringes were registered on a film during synchronous 
measurement of force. The scheme of the test shield with a hole is shown in Figure 2.

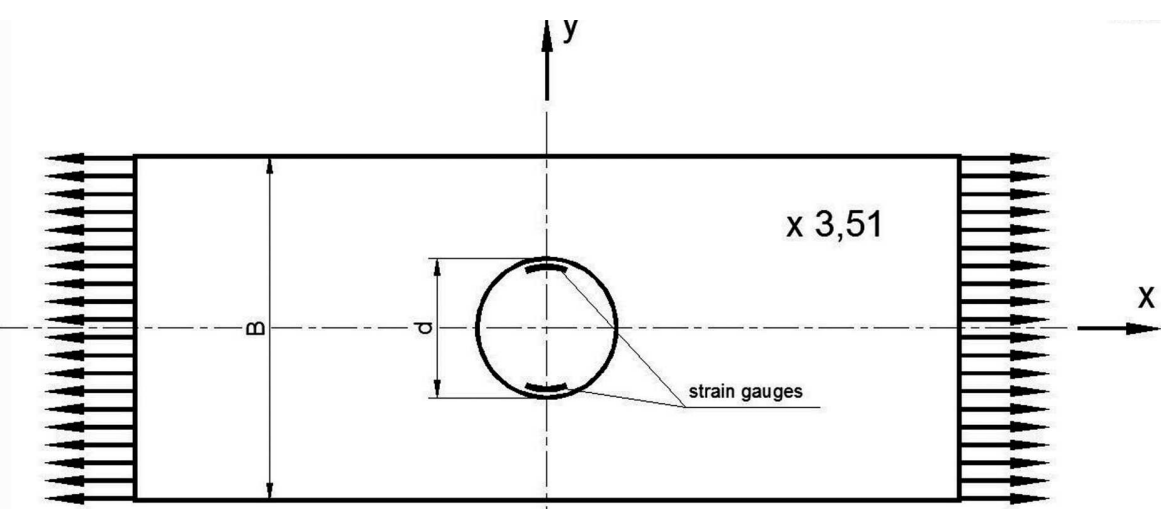

Fig. 2. Structural scheme of the shield with the opening

In the following discussion, it will be convenient to introduce the nominal stress $\sigma_{n}$ calculated as the ratio of the loading force $P$ to the shield's crosssectional area outside the hole $S_{0}$ :

$\sigma_{n}=\frac{P}{S_{0}}$, where: $S_{0}=88.4 \times 3.51=310.284\left[\mathrm{~mm}^{2}\right]-$ cross sectional area of the shield outside the hole.

The concept of dimensionless stress initiating the process of plastic flow calculated with use of a finite element method will be employed in some considerations. This stress is calculated for the force causing the first plastic slips.

$\bar{\sigma}_{i x}=\frac{\sigma_{x \max }}{R_{e H}}$ and $\bar{\sigma}_{i H M H}=\frac{\sigma_{i H M H}}{R_{e H}}$, where:

$\bar{\sigma}_{i x}$ - dimensionless stress in the $\mathrm{x}$ direction initializing plastic slip on the lateral surface of the hole,

$\bar{\sigma}_{i H M H}$ - dimensionless reduced stress initializing plastic slip on the lateral surface of the hole,

$\sigma_{x \max }, \sigma_{i H M H}$ - maximal stress values on the lateral surface of the hole, $R_{e H}$ - upper yield point value of shield material from the static tensile test.

\section{Determination of mechanical properties of the test shields material}

Figure 3a shows a graph of the tensile test of a specimen made of the material of the examined shields i.e. steel $\mathrm{C} 45$ with a zoomed exact image of the plastic platform. In Figure $3 b$, there is shown the characteristic layout of the interference fringes in the phase where only part of the sample has reached a plastic state. 

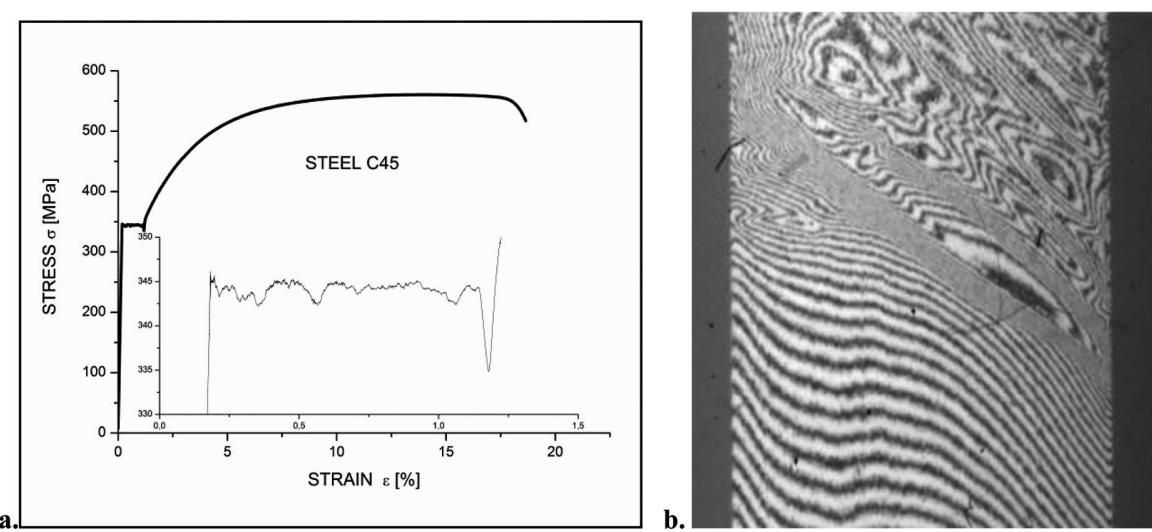

Fig. 3. Graph of steel C45 tensile test, and the picture of interference fringes on the steel $\mathrm{C} 45$ specimen under tension at the point of tensile test graph placed on the platform of plasticity

Based on the graphical results of the tensile test shown in Fig. 3 the values of Young's modulus $(E=189[\mathrm{GPa}])$ and the upper Yield Point $\left(R_{e H}=346[\mathrm{MPa}]\right)$ were determined.

In the case of the steel $\mathrm{C} 45$ examined by means of the optical interference method, the shape of the interference fringes in the plastic zone exhibited some abnormality in comparison with other steels with material instability (i.e. S235, S355, 15CrMo, Armco iron), where at the first onset of plastic deformations one observed vanishing of the interference fringes. In the C45 steel, in the first stage of plastic strain formation, a significant change in the interference fringes was observed - it was local concentration or local, short-lived, occasional and transitional loss of fringes.

The effect mentioned above the authors intended to show in the Fig. 3b, where the three fringe layouts of different character one could observe in the same moment of time. Namely, in the lower part of the photograph the view for the elastic state is visible. In the central part of the photo one can observe two closely spaced bands with few visible concentrated fringes, corresponding to the onset of plastic deformation. The bands moved along the specimen length - the phenomenon is clearly visible on the movie being in the author's disposal. In the upper part of the sample's picture - the fringes of non-typical shape - on the film it is possible to observe changes in their shapes and slow disappearance of them.

\section{Analysis of the formation of plastic area around the opening $\phi 4$}

\subsection{Experimental study of the disk with a $\phi 4$ hole}

Since it was not possible to stick an extensometer on the side surface of the $\phi 4$ hole, it was not possible to track strain changes in the zone of 
the maximum strain values. The conclusions about strain character in the hole zone can therefore only be based on the analysis of the registered film. The observation of the image of interference fringes changes during the experiment and the subsequent analysis of the recorded video showed neither the occurrence of rapid changes in the layout of fringes, nor - in particular their disappearance. Figure 4 presents four photos extracted from the video, showing the typical stages of the disk deformation process. The photograph in Figure 4a shows the layout of fringes with a preload of $5[\mathrm{kN}]$. The lack of symmetry in the arrangement of interference fringes around the opening is the result of imperfection of hand-polishing of the shield surface, rather than the result of unbalanced load and shield deflection. The fringes in the form of regular stripes of arcs based on the circumference of the hole appeared successively in the zone where $\sigma_{x \max }$ occurred in the wake of the growing load.
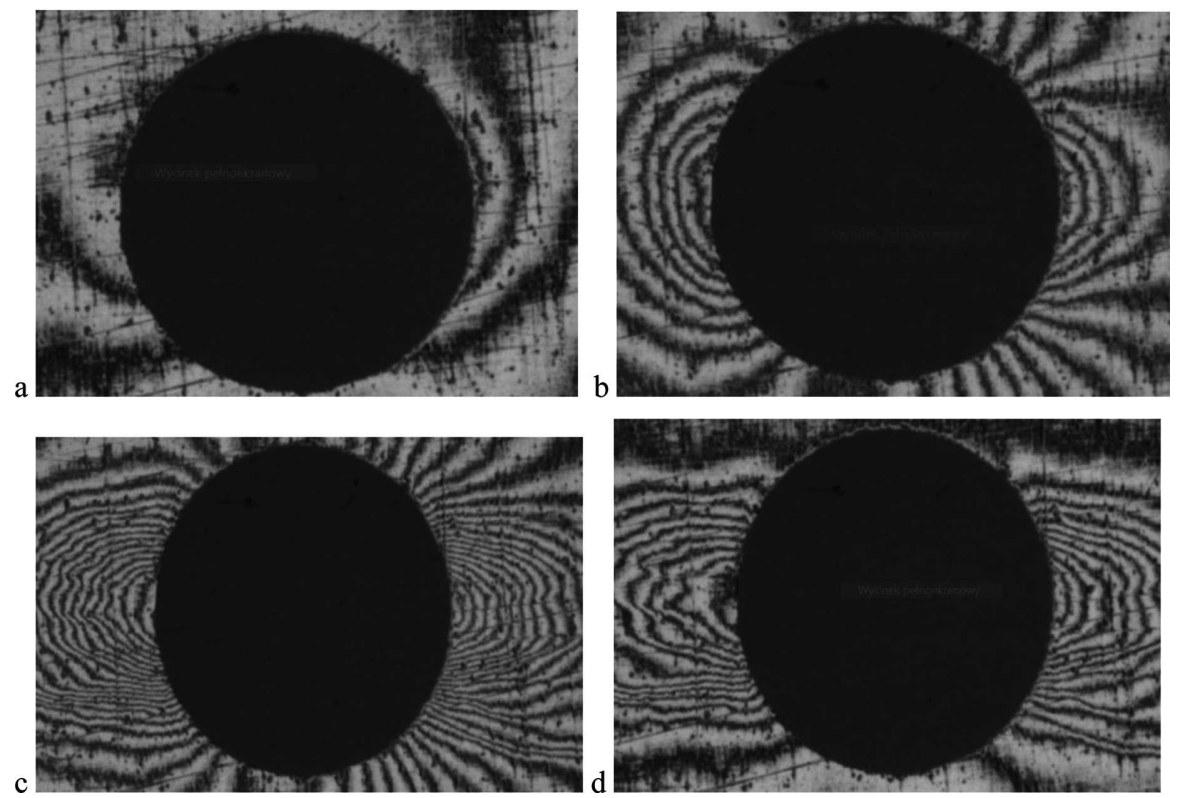

Fig. 4. Arrangements of the interference fringes in the shield around the hole $\phi 4: a-$ for a preload of $5[\mathrm{kN}], \mathrm{b}-$ for a load of $80[\mathrm{kN}], \mathrm{c}-$ for a load of $101[\mathrm{kN}], \mathrm{d}-$ when fully unloaded

The first collapse of the fringes' shape occurred at the edge on both sides of the hole for the load of $\approx 80.0[\mathrm{kN}]$, as shown in the photograph in Figure $4 \mathrm{~b}$. These effects can be interpreted as the signals that plastic slips occur in the shield mid-surface. The maximum stress value on the hole lateral surface, determined from the stress concentration ratio, is $\sigma_{i x}=2.23 \times R_{e}$ at the same value of load. When the load exceeded $80[\mathrm{kN}]$, the number of 
fringes in the $\sigma_{x \max }$ zone grew fast. It indicates the formation of depressions connected with an intense growth of $\varepsilon_{x}$ and $\varepsilon_{z}$ on both sides of the opening.

A load was applied on the shield, increasing to the force of $101[\mathrm{kN}]$, and afterwards an unloading process took place. The image of fringes for the maximum force is shown in Figure 4c. In the final phase of the process of loading, in the image of fringes having form of circle shaped arcs, appeared the forms looking like slightly curved arrow-heads.

Inside these "arrowheads", there occurred very dense fringes, characteristic for the plastic zone in C45 steel. This effect was an evidence for the fact that plastic zone appeared on the outer surface of the shield.

Figure $4 \mathrm{~d}$ shows the image of fringes after complete unloading of the shield, where the fringe forms looking like arrowheads are also visible. The number of closed curved fringes was reduced from 13 at the maximum force to 10 after unloading.

\subsection{Numerical stress state analysis around the hole $\phi 4$}

The calculations of stresses and strains for the shield with a $\phi 4$ hole were made for the load at which one noted the first collapses of interference fringes in the experiment, i.e. at $80.0[\mathrm{kN}]$. The results of the calculations are shown in the following figures: Figure $5 \mathrm{a}-\sigma_{x}$ stress distribution, Figure $5 \mathrm{~b}-\sigma_{y}$ stress distribution, Figure $5 \mathrm{c}-\sigma_{z}$ stress distribution, Figure $5 \mathrm{~d}-$ $u_{z}$ displacement distribution. Figure 5e shows the picture of Huber-MisesHencky reduced stress distribution; the line corresponding to the yield point (346 MPa) is also shown. All of these stresses reach their maximum values in the mid-surface of the shield. The figures include half the thickness of the shield. Stress distributions shown here clearly indicate the substantial heterogeneity of the stress components along the thickness of the shield. For example, the stress $\sigma_{z \max }=79.4[\mathrm{MPa}]$ equals $9.8 \%$ of the maximum stress $\sigma_{x \max }=811.7[\mathrm{MPa}]$ and $10.3 \%$ of the $\sigma_{H M H \max }=767[\mathrm{MPa}]$ maximum value.

Therefore, in the considered case, a flat state of stress cannot be assumed, and the stress gradients that occur restrict the freedom of plastic slips appearance in the direction of the shield surface This might result in the disappearance of, or a sudden shift in the interference fringes' layout. For the extending force of $80.0[\mathrm{kN}]$, the dimensionless initiating stress equals $\bar{\sigma}_{i H M H}=2.22$.

\subsection{Analysis of the phenomena around the hole $\phi 4$}

The conducted experiment indicates an insufficient sensitivity of the optical interference method for the identification of plastic deformation around 

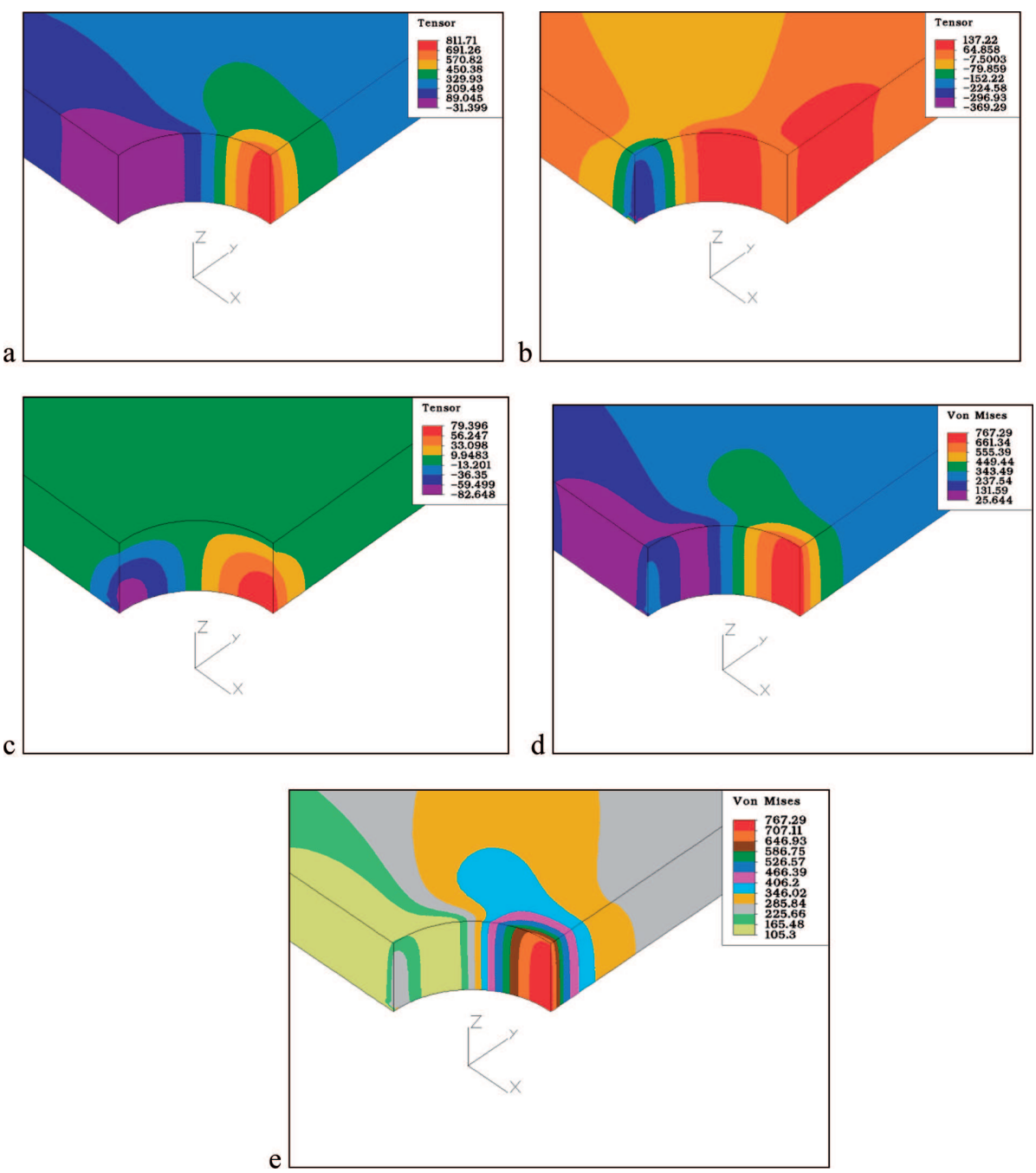

Fig. 5. Stress distributions around the $\phi 4$ hole calculated with the use of the finite element method for $80[\mathrm{kN}]$ loading: $\mathrm{a}-\sigma_{x}$ stresses, $\mathrm{b}-\sigma_{y}$ stresses, $\mathrm{c}-\sigma_{z}$ stresses, $\mathrm{d}-u_{z}$ displacement, half the change of the disk thickness, e $-\sigma_{H м H}$ reduced stresses, the value $R_{e}$ between yellow and blue colours

holes with diameters comparable to the thickness of the expanded shield. One of important reasons for this effect is a significant deviation from the flat state of stress observed in small holes. This deviation is shown with the use of FEM calculations. The deviation from the flat state of stress causes that a plastic slip is initiated in the area of the shield mid-surface. Due to the stress gradient, the development of plastic slip on the outer surface is retarded. Namely, the onset of plastic slips requires that the stress at the hole increases up to the level initiating the plastic deformation. 
It should also be noted that the case of a disk with a hole $\phi 4$ is basically very similar to the classical problem of a hole trepanation method. In 2004, a research was performed [3] - without the use of the optical interference method as this was unknown at the time - which indicated that, for the hole of $\phi 2$, only at the loading which causes maximal stress on the shield surface at the hole, equal to $\approx 2.4 \times R_{e}$, the effects indicating the presence of plastic deformations were observed.

In particular, the effect of an "orange peel" was noted on the surface of the shield, and a small residual deformation around the hole appeared after unloading. According to the manual for the hole trepanation method published by Vishay company, it is recommended to apply the formulas based on the theory of elasticity for nominal stresses up to $0.7 \times R_{e}$. This corresponds to the stress level of $\sigma_{x \max }=2.1 \times R_{e}$ at the hole in the stretched thin shield. It can be assumed that the Vishay company recommending a limit value for a nominal stress at the level of $0.7 \times R_{e}$, has probably also assumed a certain confidence interval. To explain the noticed uncertainty of the optical interference method indications, it is required to carry out further research and analyses with the use of other research methods.

\section{Analysis of the formation of a plastic area around the hole $\phi \mathbf{1 0}$}

\subsection{Experimental study of the shield with a $\phi 10$ hole}

Figure 6 shows charts of strains measured with the use of strain gauges glued on the side surface of $\phi 10$ hole (as shown in Figure 2) as a function of the shield loading force. The experiment comprised the sample loading to a significant disproportionate strain (plastic strain) and unloading. The lines corresponding to the selected values $(0,100,226,500)$ disproportionate strains, understood as the difference between the actual coordinates of the curve and the extension of the linear (elastic) part of chart are plotted on the graph. The arrow indicates the point on the graph that corresponds to the occurrence of the pulse in the system of interference fringes.

Graphs in Figure 6 show no kinks indicating the presence of plastic slips that were observed when testing the opening of the similar shield made of steel $15 \mathrm{CrMo}$ characterized by a much longer plastic platform [3]. Strain charts as above shows the first deviation from straight line for approximately $55.0[\mathrm{kN}]$ load. Therefore, one can try estimate the loads corresponding to the selected values of disproportionate strain, mindful of the strain being averaged on measurement base length by the strain gauge.

The estimation was adopted that the deformation values in the range of 55 to $60 \mathrm{kN}$ measured in relation to the maximum are understated by 


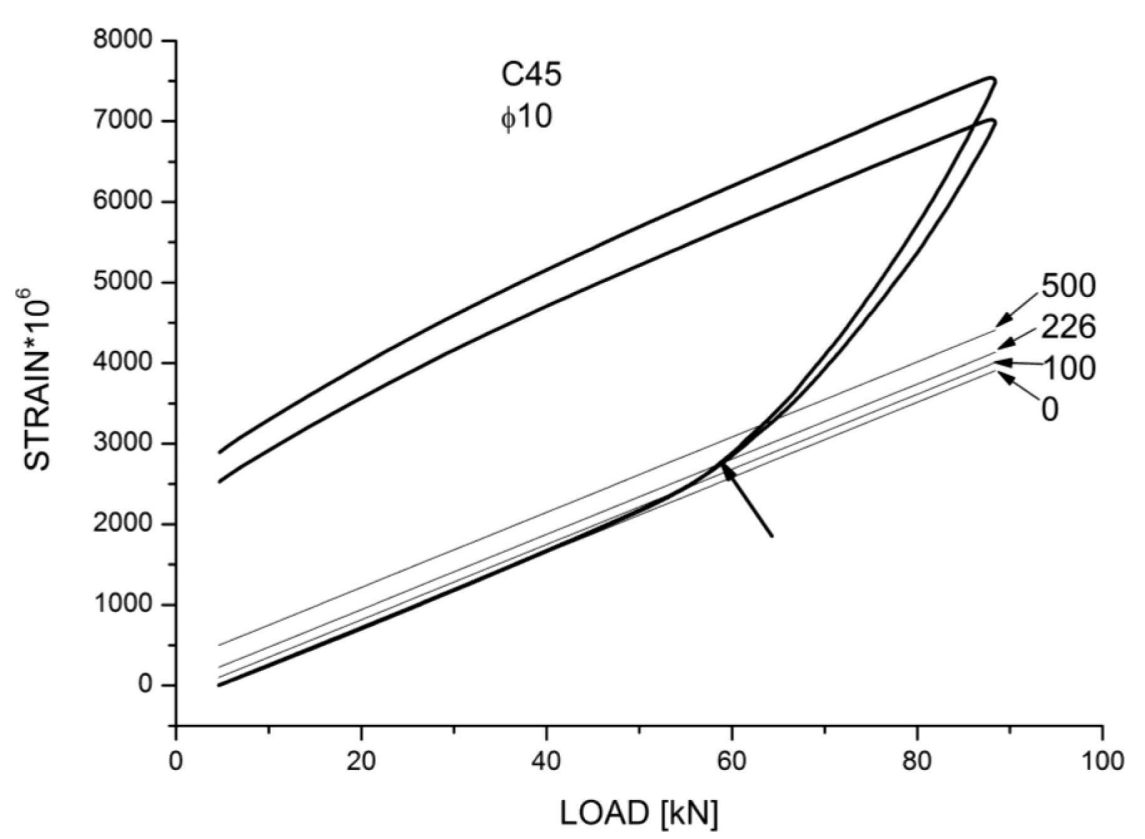

Fig. 6. Chart of strains measured by strain gauges for the $\phi 10$ hole

a similar value. For the load of $58.39 \mathrm{kN}$, for the strain gauge based on 3 [mm], and gradient occurring in the $\varepsilon_{\max }$ strain zone, the strains indicated by strain gauge are understated for $(2.0 \div 2.5) \times 10^{-4}$ from $\varepsilon_{\max }$ value. Thus, the maximum disproportionate strain of $\bar{\varepsilon}_{p}=2.26 \times 10^{-4}$, measured at such load, actually reaches a value of $\varepsilon_{p}=(4.5 \div 5.0) \times 10^{-4}$, which corresponds to the strain of a conventional elastic limit. In the video film, one can notice the impulse in the image interference fringes, coming from the inside of the disc, that occurred close to the above-mentioned upper value of loading force compartment (i.e. for approx. $58.39 \mathrm{kN}$ ). The result of the impulse for the fringes layout is shown in Figure 7a.

With the loading above $58.390[\mathrm{kN}]$, the formation of a plastic zone in a form of slightly curved tips initiating from the hole edge was observed. The number and the length of these tips increased with an increase in loading.

Fringes in the shape of stripes similar to the circular arcs based on the edge of the hole were also formed. The outermost fringe constitutes a kind of a boundary of the tips formed as zones of plastic slip. The next phases of development of the above-discussed phenomena, which can be interpreted as the propagation of plastic zones, are shown in Figure $7 \mathrm{~b}$ for loading of $73.8[\mathrm{kN}]$, and in Figure $7 \mathrm{c}$ for the fringes' arrangement for a loading force of $88.2[\mathrm{kN}]$, followed by unloading. The arrangement of fringes after complete unloading is shown in Figure $7 \mathrm{~d}$; the reduction of the number of fringes forming arcs based on the hole edge from 17 to 13 in comparison to 

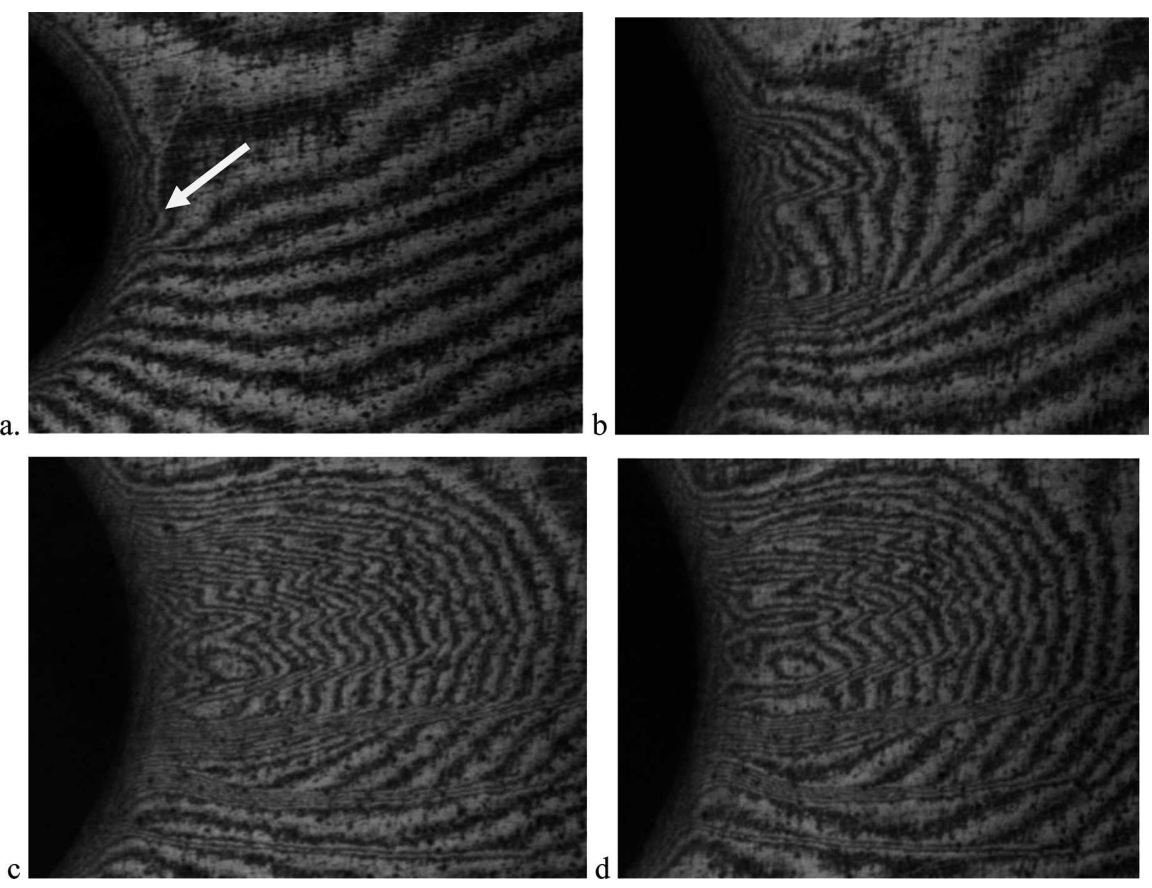

Fig. 7. Pictures of interference fringes' schemes at the $\phi 10$ hole: a. - for $58.39[\mathrm{kN}]$ loading, b. for $73.8[\mathrm{kN}]$ loading, c. - for $88.2[\mathrm{kN}]$ loading, d. - after shield complete unloading

Figure 7c is visible. Characteristic fringes' arrangements in the form of tips signalling plastic slips remained after unloading.

\subsection{Numerical analysis of the stress state around the $\phi 10$ hole and its comparison with the experiment results}

Numerical calculations of stress and strain with the use of the finite element method for the shield with a $\phi 10$ hole were performed for $58.39[\mathrm{kN}]$ loading designed in an experiment as one causing the first plastic deformations. The results of the calculations are shown in Figure 8, namely: Figure $8 \mathrm{a}-\sigma_{x}$ stress distribution, Figure $8 \mathrm{~b}-\sigma_{y}$ stress distribution, Figure 8c $-\sigma_{z}$ stress distribution, Figure $8 \mathrm{~d}-u_{z}$ displacement distribution, whereas Figure 8e shows the picture of the distribution of Huber-Mises-Hencky reduced stresses with the line corresponding to the yield point indicated in the picture. All these stresses reach their maximum values in the mid-surface of the shield, but the figures include half the thickness of the disk. The $\sigma_{z}$ stresses shown in Figure 8c reach small values and their maximum values appear in the mid-surface and are equal to $2.6 \%$ of the $\sigma_{x}$ stress maximum value. The stress state around the hole differs only slightly from the plane state of stress. 

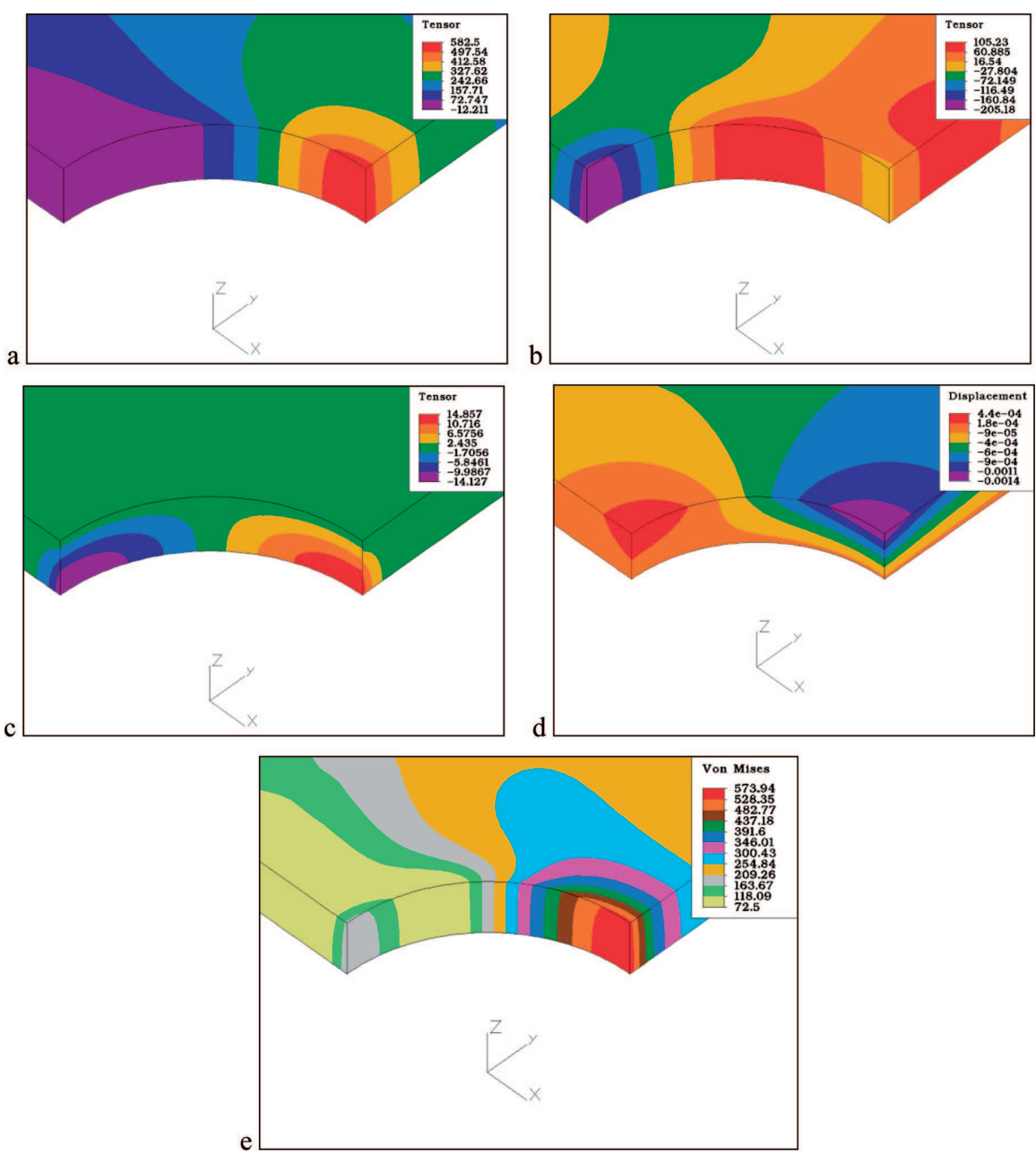

Fig. 8. Distributions of stresses around the $\phi 10$ hole calculated with the finite element method for $58.39[\mathrm{kN}]$ loading: $\mathrm{a}-\sigma_{x}$ stresses, $\mathrm{b}-\sigma_{y}$ stresses, $\mathrm{c}-\sigma_{z}$ stresses, $\mathrm{d}-u_{z}$ displacement (changes of the half the thickness of the shield), e $-\sigma_{H M H}$ reduced stress, the $R_{e}$ value between light purple and blue colours

The maximum stress $\sigma_{x}=582.5[\mathrm{MPa}]$ calculated by the FEM corresponds to the value $\bar{\sigma}_{i x}=1.68$, whereas the $\sigma_{H M H}=574[\mathrm{MPa}]$ reduced stress corresponds to the value $\bar{\sigma}_{i H M H}=1.66$.

The area shown in Figure 8e that is limited on the outside by a curve or, in fact, by the surface of the equation $\bar{\sigma}_{H M H}=1$ (i.e. $\sigma_{H M H}=R_{e H}=$ $346[\mathrm{MPa}])$ can be interpreted as the area which stores elastic energy required to run the first plastic slip. In the future, it seems reasonable to attempt to determine the value of the originator energy, i.e. the energy required to initiate plastic slips in a heterogeneous state of stress. 


\section{Analysis of the plastic area formation around the $\phi 20$ hole}

\subsection{Experimental study of a disc with the hole $\phi 20$}

Graphs of strain changes measured with strain gauges versus the shield loading force are shown in Figure 9, and the interference fringes' images around the hole $\phi 20$ selected from the film are shown in Figure 10, namely: $10 \mathrm{a}$ - for preloading ; 10b - for loading 46.968 [kN]; 10c - for loading 59.6 $[\mathrm{kN}] ; 10 \mathrm{~d}-$ after complete unloading of the shield.
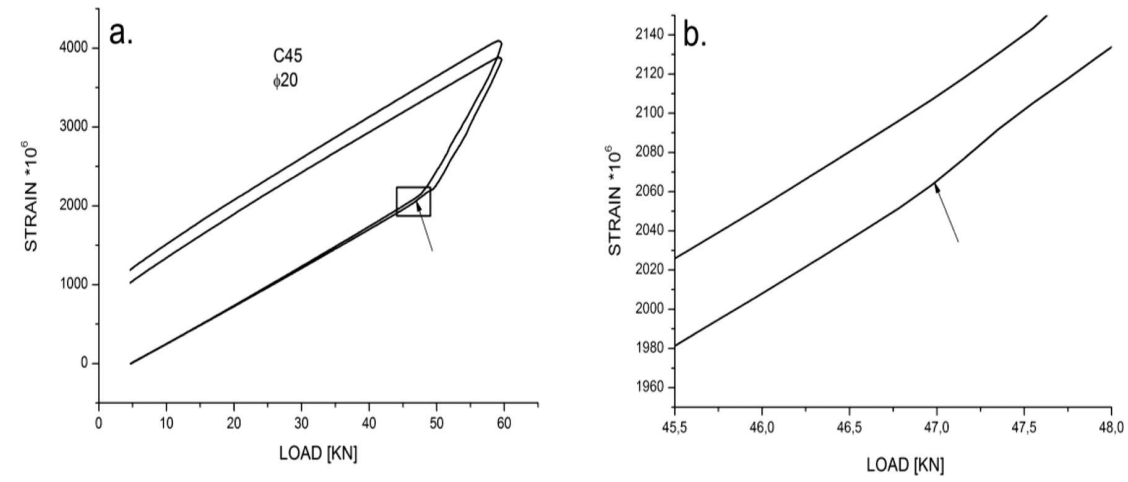

Fig. 9. Graphs of strains measured with strain gauges on the circumference of the $\phi 20$ hole
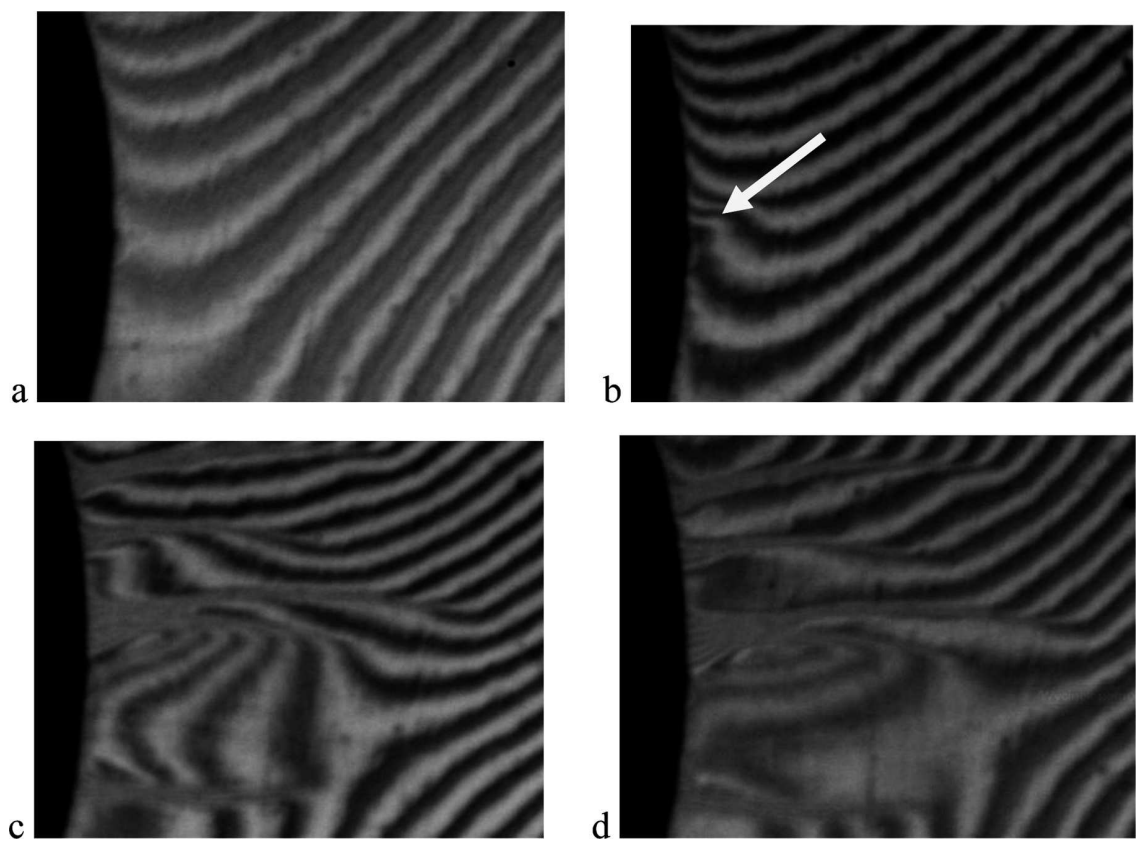

Fig. 10. Pictures of interference fringes' layouts around the $\phi 20$ hole: $\mathrm{a}-$ for $0[\mathrm{kN}]$ loading; $\mathrm{b}-$ for $46.98[\mathrm{kN}]$ loading; $\mathrm{c}$ - for $59.6[\mathrm{kN}]$ loading; $\mathrm{d}$ - after complete unloading of the shield 
The first slight break observed in the strain graph for the $P=46.97[\mathrm{kN}]$ tensile force is the evidence of the occurrence of the first plastic slip. Observation of the interference fringes layout indicates that the slip begins in the area of the shield mid-surface. At the same time, a gentle twitch of fringes close to the hole diameter perpendicular to the tensile direction could be observed on the outside surface of the disk. It is shown in Figure 10b.

During the following small increase in the tensile force, a clear discontinuity in the interference fringes occurred in this area, i.e. at the place of the first noticeable twitch in the fringes' image (Fig. 10c). With a further increase in the shield loading, another area of plasticity initiates next to the first plastic zone. This new area has a similar but less classical form than it had at the opening of $\phi 10$. Figure 10c shows the interference fringe system for an extreme load of $59.6[\mathrm{kN}]$, and in Figure 10d the fringe system after a complete relief of the test shield is shown.

\subsection{Numerical analysis of stress around the hole $\phi 20$ and comparison with the results of the experiment}

The numerical analysis of the stresses around the hole $\phi 20$ was shown in [5], but the shield was of another size and it was made of a different material. It justifies the presentation of the calculation results for the shield considered in this study due to significant quantitative differences. Calculations were made for the shield under the loading force of $46.97[\mathrm{kN}]$ corresponding to the first break in the interference fringes' arrangement. The calculation results are shown for half the thickness of the shield in the following figures: Figure $11 \mathrm{a}-\sigma_{x}$ stress distribution, Figure $11 \mathrm{~b}-\sigma_{y}$ stress distribution, Figure $11 \mathrm{c}-\sigma_{z}$ stress distribution, Figure 11d - distribution of $u_{z}$ displacement, and Figure 11e shows the distribution of the reduced stress $\sigma_{H M H}$ with a depicted border of the area in which $\sigma_{H M H} \geq R_{e}$. It should be noted that the tension $\sigma_{z}=5.5[\mathrm{MPa}]$ constitutes now only $1.1 \%$ of the maximum value $\sigma_{x \max }=488.5[\mathrm{MPa}]$. Therefore, the state of stress at the hole $\phi 20$ is similar to a flat state.

The dimensionless values of the stresses at the maximum material effort on the side surface of the hole are as follows: $\bar{\sigma}_{i H M H}=1.40$, but $\bar{\sigma}_{i x}=$ 1.41. They are about $16 \%$ lower than those determined for the hole $\phi 10$. In view of the higher value of the stress gradient around the hole $\phi 10$, the above stress values initializing the plastic flow for the hole $\phi 20$ do not raise objections. Much higher compliance of dimensionless initializing stresses occurs for the above results and those obtained for the $\phi 20$ hole in the shield of steel 15CrMo [5]. 

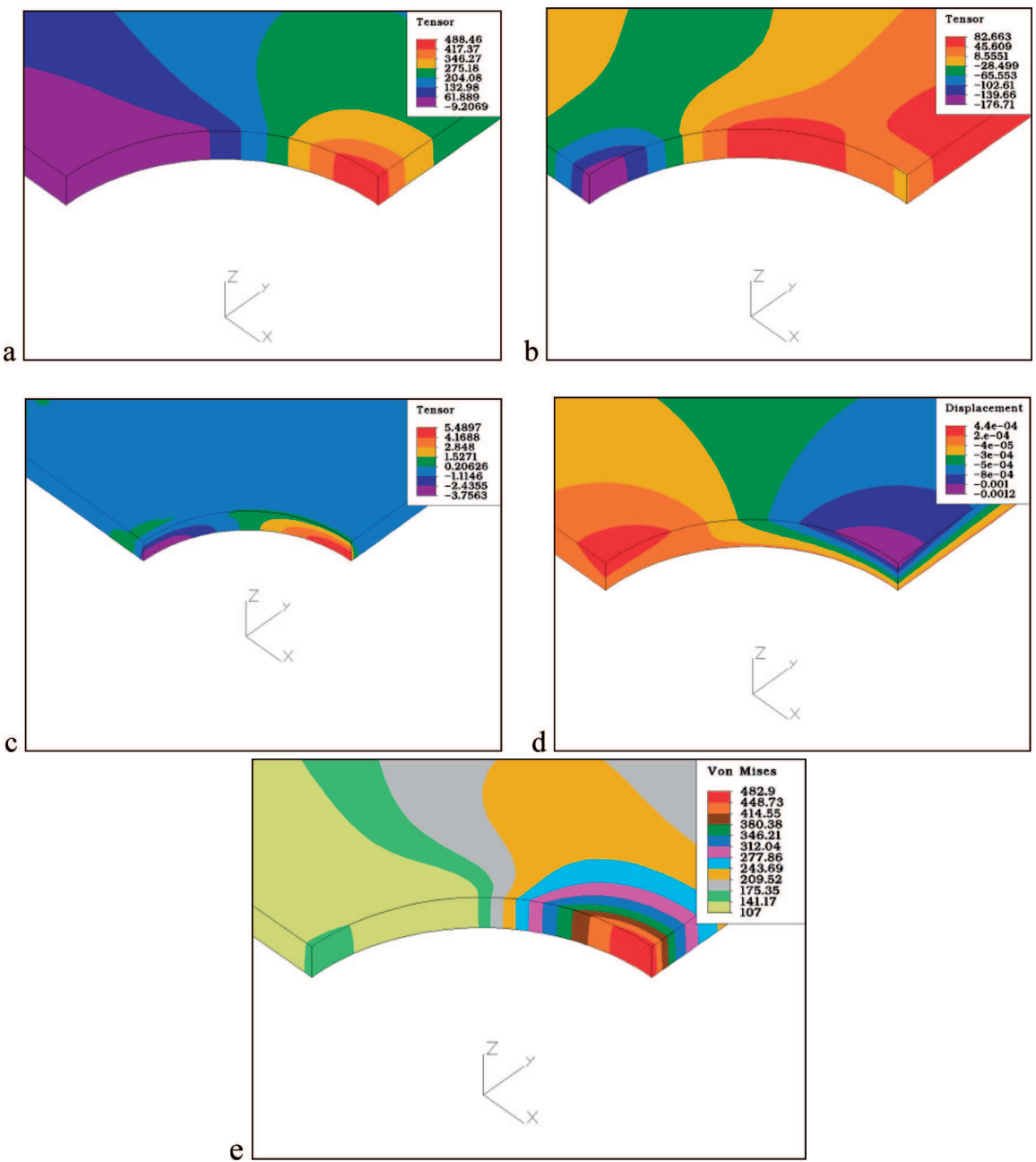

Fig. 11. Stress distributions around the $\phi 20$ hole calculated by the Finite Element Method for 46.97 [kN] loading: $\mathrm{a}-\sigma_{x}$ stresses, $\mathrm{b}-\sigma_{y}$ stresses, $\mathrm{c}-\sigma_{z}$ stresses , $\mathrm{d}-u_{z}$ displacement, half of the shield thickness change, e $-\sigma_{H M H}$ reduced stresses, the $R_{e}$ value between blue and green colours

\section{Summary of the results of research and analyses}

For the hole with a diameter of $4.0[\mathrm{~mm}]$ in the shield of $3.51[\mathrm{~mm}]$ thickness, the effectiveness of the optical interference method is debatable. The change of the fringes' image after the plastic deformations is explicit, however, verification methods which were used were not accurate enough for reliable confirmation of the start of the plastic deformation process. An analogy between this case and a classic problem occurring in the hole trepanation method is significant. The result obtained in the experiment shown is very similar to the one obtained previously by S. Bućko and H. Jodłowski in [2]. In 
the case of holes $\phi 10$ and $\phi 20$, the stress state in the zone of maximal effort at the hole is very close to the plane state of stress, especially for the stress state at an opening of $\phi 20$. Calculations performed with the use of the finite element method and with the use of Howland formula justify the assumption that $\sigma_{1} \cong \sigma_{x}>0, \sigma_{2} \cong \sigma_{y}>0$ and $\sigma_{3} \cong \sigma_{z} \cong 0$. In such a state of stress, the following relationships can be assumed: $\tau_{\max }=\frac{1}{2}\left(\sigma_{I}-\sigma_{I I I}\right) \cong \frac{1}{2} \sigma_{I} \cong \frac{1}{2} \sigma_{x}$. The plane of the $\tau_{\max }$ stress in the zone of the hole will pass the hole diameter perpendicular to the tensile direction and will be inclined to the plane of the shield at the angle $\approx 45^{\circ}$, as shown in Figure 12 .
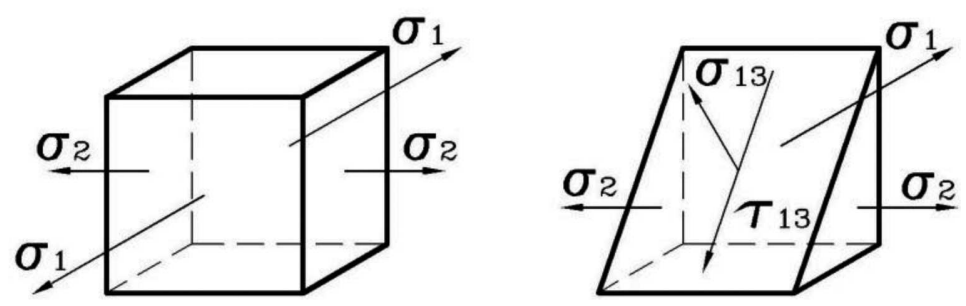

Fig. 12. The image of the stress state in the zone of the maximal effort at the hole with a diameter significantly greater than the thickness of the shield with the indication of the course of $\tau_{\max }=\tau_{1,3}$ acting

The interference fringe systems shown in Figure 7 and Figure 10 differ one from another. However, in both figures the schemes forming slightly curved "arrow tips" occur. Similar fringe systems are observed in Figure 4 for the shield with a $\phi 4$ hole. The differences in the observed fringe systems are inevitable due to the hand polishing of the observed fragments of the surface and due to ongoing changes of the thickness of the gaps between shields and semi-transparent mirrors. It should also be noted that in the three tested shields the fringe systems characteristic for the steel C45 samples are observed, i.e. in the slip area there appear fringes with a significantly higher density in relation to the arrangements in the elastic zones and the disappearance of fringes occurs only with large plastic deformations.

The charts of reduced stresses calculated with the use of the finite element method for the loads corresponding to the signals indicating the formation of the first plastic deformations (the results of which are presented in Figures $5 \mathrm{e}, 8 \mathrm{e}$ and $11 \mathrm{e}$ ) show a very small size of the areas with an excess of the yield point.

Therefore, the conducted experimental studies have shown the effectiveness and credibility of the optical interference method in identifying plastic macrostrains in tensioned shields with holes whose diameters are several times bigger than the thickness of the shield. This was demonstrated for diameters of $\phi 10$ [mm] and $\phi 20[\mathrm{~mm}]$ with the 3.51 [mm] shield thickness. The authors' 
previous works [2], [3], [5] led to similar conclusions. The evaluation of the effectiveness of the optical interference method in identifying plastic deformations around the holes whose diameters are close to the thickness of the tensed shield requires more research with the use of other methods of verification.

Showing a local character of plastic deformations in the phase of their appearance is an important conclusion of the research presented in the paper

The observed phenomenon needs a particular method of analysis that significantly differs from the schematic methods applied in the analysis used for mechanics of continuum.

\section{Acknowledgment}

The scientific work financed by National Center of Science from funds for science 2010-2013 as a research project N N501248838, Decision No 2488/B/T02/2010/38

Manuscript received by Editorial Board, July 24, 2013; final version, February 20, 2014

\section{REFERENCES}

[1] Brzoska Z.: Wytrzymałość Materiałów, Warszawa 1973.

[2] Bućko S., Jodłowski H.: „Metoda trepanacji otworowej - podstawy teoretyczne i praktyka jej stosowania w pomiarach naprężeń. " Czasopismo Techniczne z. 13-M/2004, Wydawnictwo Politechniki Krakowskiej.

[3] Bućko S., Jodłowski H.: Inicjacja odkształceń plastycznych w stali z wyraźną granicą plastyczności w warunkach gradientu naprężeń, Acta Mechanica et Automatica, v. 3, nr 1, 2009.

[4] Bućko S., Jodłowski H.: Inicjacja odkształceń plastycznych w stalach z niestatecznością materiałową w warunkach rozciagania i czystego zginania, Czasopismo Techniczne nr 4, 2010.

[5] Bućko S., Jodłowski H., Trzebicki M.: „Numerical-experimental analysis of plastic flow beginning phase round the hole in the thin shield under tension"; Acta Mechanica et Automatica, vol. 6 no 1 (2012).

[6] Durelli A.J., Parks V.J.: Moire Analysis of Strain. Prentice-Hall, Englewood Cliffs, New Jersey 1970.

[7] Howland R.C.J. (1930), On the Stresses in Neighborhood of a Circular Hole in a Strip Under Tension, Phil. Trans. Roy. Soc. (London), A, Vol. 229 (1929-30), p.67.

[8] Jodłowski H.: Metoda rozpoznawania odkształceń plastycznych w procesie obciążania stali wykazujących niestateczność materiałową: Praca doktorska, Politechnika Krakowska, Wydział Mechaniczny, Kraków 2007.

[9] Jodłowski H.: Doświadczalne wyznaczanie stref plastycznych w stalach z wyraźną granicą plastyczności. Badania Eksperymentalne w Mechanice Ciała Stałego. Prace Naukowe Politechniki Warszawskiej. Mechanika z. 217 (2007).

[10] Kadaniew A.I.: Koncentracija napriażenij w płasticzeskoj obłasti, „Trudy Akademii”, wyp. 316, izd.WWIA im. N. E. Żukowskogo, 1949.

[11] Nadai A.: Theory of flow and fracture of solids, v.1, Mc Graw-Hill, New York 1950. 
[12] Szczepiński W.: Mechanika plastycznego płynięcia, Warszawa 1978.

[13] Theocaris S., Marketos E.: Elastic-plastic analysis of perforated thin strips of a strainhardening material, J. Mech. Phys. Solids. 11. 1964. (377-390).

\section{Eksperymentalno-numeryczna analiza inicjacji stref plastycznych przy otworach w tarczach ze stali C45}

\section{Streszczenie}

W pracy zaprezentowano wyniki badań nad formowaniem stref plastycznych w cienkich tarczach wykonanych ze stali C45 z otworami o średnicach 4,10 i 20 milimetrów. W eksperymentach wykorzystano autorską metodę identyfikacji makro-odkształceń plastycznych za pomocą zjawiska interferencji optycznej. Główną zasadę wykorzystania tej metody można ująć w zdaniu: „O występowaniu odkształceń plastycznych w czynnym procesie obciążania świadczy zanik pierwotnie widocznych prążków interferencyjnych bądź gwałtowna zmiana ich charakteru". Wyznaczono doświadczalnie wartości naprężeń inicjujących odkształcenia plastyczne. W celu wyjaśnienia zjawisk towarzyszących inicjacji procesów towarzyszących początkowej fazie odkształceń plastycznych została przeprowadzona szczegółowa analiza stanu naprężenia w strefie otworów.

Porównanie wyników analizy eksperymentalnej z wynikami uzyskanymi za pomocą Metody Elementów Skończonych wykazało istotne różnice ilościowe i jakościowe. Mianowicie, naprężenia inicjujące odkształcenia plastyczne istotnie przekraczają wartość górnej granicy plastyczności $R_{e H}$ oraz odkształcenia plastyczne posiadają charakter towarzyszący lokalnym poślizgom plastycznym. Podobne wyniki były prezentowane uprzednio w badaniach tarcz $\mathrm{z}$ otworami wykonanych ze stali 15CrMo. 